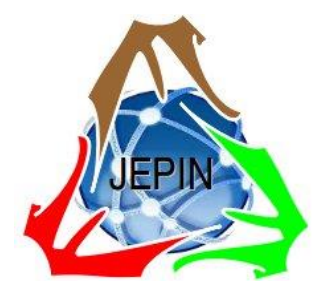

\title{
Penerapan Framework COBIT 2019 pada Audit Teknologi Informasi di Politeknik Sambas
}

Muhammad Saleh $^{\# 1}$, Ismail Yusuf ${ }^{\# 2}$, Herry Sujaini" ${ }^{\# 3}$, Steven Pragestu ${ }^{\# 4}$, Harry ${ }^{\# 5}$, M. Nur Hidayat ${ }^{\# 6}$, Irwan Adhi Prasetya $^{\# 7}$, Gita Pratiwi ${ }^{\# 8}$, Muhammad Rezza ${ }^{\# 9}$, Hariyanto ${ }^{\# 10}$, Rachman Rohendi ${ }^{\# 11}$, Muhamad Hafiz Waliyuddin ${ }^{\# 12}$

\#Jurusan Teknik Elektro, Fakultas Teknik, Universitas Tanjungpura

JL Prof Dr H Hadari Nawawi, Pontianak, Kalimantan Barat

${ }^{1}$ muhammad.saleh@ee.untan.ac.id

2 ismail. yusufdee.untan.ac.id

3herry.sujainidee.untan.ac.id

${ }^{4}$ stevenpragestulastudent.untan.ac.id

${ }^{5}$ harry mlwestudent.untan.ac.id

${ }^{6} \mathrm{~m} \cdot \mathrm{n}$. hidayatestudent.untan.ac.id

7 irwanadhi21estudent.untan.ac.id

${ }^{8}$ gitapratiwi77@student.untan.ac.id

${ }^{9}$ muhammadrezza@student.untan.ac.id

10hariyanto. toledstudent.untan.ac.id

${ }^{11}$ rachmanestudent.untan.ac.id

12mhafizwaliyuddinestudent.untan.ac.id

\begin{abstract}
Abstrak - Teknologi informasi di suatu organisasi yang sudah berjalan harus diaudit agar diketahui kelebihankelebihan maupun kekurangannya. Politeknik Sambas (Poltesa) merupakan salah satu politeknik di Kalimantan Barat yang telah menerapkan teknologi dalam proses administrasi maupun akademik sebagai penunjang kegiatannye. Audit yang dilakukan pada Poltesa menggunakan frame work COBIT 2019. Metode yang kami pergunakan pada penelitian ini terdiri dari bebrapa langkah, yaitu perencanaan, tindakan, pengamatan, pengolahan dan analisis data, serta pemberian rekomendasi. Berdasarkan hasil dari audit yang dilakukan pada teknologi informasi Poltesa, didapatkan rata-rata nilai sebesar 3,21 dengan nilai maturity level pada domain antara nilai 2 sampai dengan 4, yang berarti sistem telah dioperasikan dengan baik, akan tetapi belum secara maksimal. Manajemen teknologi informasi yang diharapkan di Poltesa dapat dipenuhi dan telah dilakukan dengan baik, karena nilai antara rata-rata level saat penelitian dilakukan dibandingkan dengan rekomendasi level menunjukkan gap yang tidak terlalu besar.
\end{abstract}

Kata kunci- Audit IT, Cobit 2019, Teknologi Informasi Poltesa

\section{Pendahuluan}

Penggunaan teknologi informasi (information technology yang selanjutnya disebut IT) sangat membantu dalam kegiatan yang menunjang proses administrasi dan akademik bagi semua stakeholder di lingkungan institusi perguruan tinggi. Diharapkan semua pengguna teknologi ini terlibat untuk memudahkan proses mendapatkan informasi. Teknologi informasi hingga sekarang akan membantu meningkatkan efektifitas dan efisiensi proses yang akan berlangsung, maka dari itu untuk mencapainya dibutuhkan suatu pengelolaan teknologi informasi secara teratur dan terstruktur.

Penyusun dasar dari suatu layanan IT adalah infrastruktur IT. Suatu layanan IT hanya dapat bekerja secara optimal jika mempunya infrastruktur yang handal. Infrastruktur IT tidak hanya terdiri perangkat keras namun juga dibangun oleh perangkat lunak seperti sistem operasi, aplikasi middleware dan basis data [1]. Infrastruktur IT perlu didukung oleh sistem evaluasi dimana evaluasi hal tersebut dibutuhkan untuk menilai dan mempertimbangkan apakah proses kerja yang telah dilaksanakan telah layak atau perlu dilakukan pembenahan selanjutnya. Oleh karena itu, evaluasi tentang implementasi teknologi informasi yang berkaitan infrastruktur IT diperlukan oleh organisasi untuk melihat apakah telah dikelola dengan baik atau tidak.

Tata kelola IT yang baik harus dapat diaudit. Audit bertujuan untuk mengevaluasi Infrastruktur IT sehingga dapat digunakan sebagai dasar untuk meperbaiki kesalahan maupun penyimpangan yang terjadi. Dalam implementasi, hasil evaluasi dari audit dipergunakan sebagai alat untuk menilai maturitas suatu organisasi [2]. 
Hasil yang diperoleh dari evaluasi audit tata kelola infrastruktur IT digunakan sebagai masukan bagi pihak berkepentingan serta sebagai bahan tolak ukur untuk memperbaiki manajemen dan untuk memperluas pengetahuan dalam penggunaaan Control Objective for Information and related Technology (COBIT) 2019 sebagai landasan atau kerangka kerja dalam menilai tata kelola suatu Infrastruktur IT pada organisasi.

COBIT mempunyai fokus pada wilayah perencanaan (plan), organisasi (organise), memperoleh hasil (acquire) dan implementasi (implement). COBIT merupakan suatu kerangka dalam tata kelola IT untuk memperoleh nilai dari kesenjangan antara permasalahan teknis, resiko dan pengendalian. COBIT merupakan suatu kerangka yang disusun oleh oleh Information System Audit and Control Associtation (ISACA) dan IT Governance Institute (ITGI) [3]. COBIT memuat kerangka-kerangka yang dapat digunakan sebagai patokan dalam tatakelola IT. COBIT digunakan untuk mempermudah memahami audit IT serta memanajemen keuntungan dan resiko yang dapat terjadi [2]. COBIT membantu mencari solusi dalam audit IT melalui pemahaman domain, model maturiti, wilayah domain, tujuan yang dicapai, proses kegiatan yang dilakukan secara terstruktur dan logis. Selain itu COBIT membantu dalam melakukan optimisasi teknologi informasi, memberikan strandar yang jelas dan memastikan penyampaian layanan yang efektif untuk manajemen[4]. COBIT 2019 Merupakan framework terbaru dari ICASA yang diterbitkan untuk memperbaharui COBIT 5 [5]

Tujuan dari penelitian ini adalah untuk memperoleh hasil analis dengan menggunakan framework COBIT 2019. Dengan pendekatan deskriftif kualitatif untuk memperoleh analisis maturity level berdasarkan hasil wawancara atau survey, melakukan analisis kesenjangan (gap) dan Menyusun rekomendasi mengacu pada Procces Assement Model (PAM). Tujuan akhir dari penelitian ini adalah melakukan audit infrastruktur IT pada Politeknik Sambas (Poltesa) untuk memperoleh hasil tingkat maturiti digunakan sebagai suatu rekomendasi demi perbaikan tata kelola Infrastruktur IT Poltesa kedepannya.

Penelitian terhadap Infrastruktur IT telah banyak dilakukan oleh banyak peneliti, namun fokus objek penelitian, lokasi, kerangka dan metode yang berbeda. Sebagai contoh penelitian Infrastruktur IT sejenis yang dilakukan dengan lokasi yang berbeda namun penelitian yang berfokus pada IT menggunakan kerangka yang berbeda [1-2][6-12]. Pada paper ini, dipaparkan hasil penelitian yang dilakukan dengan menggunakan framework COBIT 2019. Untuk penelitian terdahulu [5,11] menggunakan framework yang sama yaitu COBIT 2019 namun untuk penelitian [11] fokusnya kepada evaluasi pada Sistem pemerintahan berbasis elektronik (SPBE) pada Direktorat Jenderal Pendidikan Tinggi. Sedangkan Penelitian yang dilakukan oleh [5] lebih berfokus kepada keamanan sistem pemerintahan menggunakan framework COBIT 19.
Pertanyaan yang timbul adalah bagaimana mengimplementasikan framework COBID 2019 pada SPBE [11] namun juga dapat menilai hingga pelayanan fisik maupun jaringan IT di dalam organisasi itu sendiri. Oleh sebab itu peneliti mengimplementasikan COBIT 2019 ini ke dalam infrastruktur IT tidak hanya dalam proses pembuatan SPBE namun ke pelayanan fisik jaringan IT pada Poltesa Pontianak.

\section{A. COBIT 2019}

COBIT (Control Objective for Information and Related Technology) adalah framework untuk tata kelola dan pengelolaan informasi dan teknologi. COBIT mendefinisikan komponen untuk membangun dan menopang sistem tata kelola: proses, struktur organisasi, kebijakan dan prosedur, arus informasi, budaya dan perilaku, keterampilan, dan infrastruktur [13].

Kerangka COBIT membuat perbedaan yang jelas antara tata kelola dan manajemen. Tata kelola memastikan bahwa: kebutuhan, kondisi dan pilihan pemangku kepentingan dievaluasi untuk menentukan tujuan perusahaan yang disepakati dan seimbang. Arah ditetapkan melalui pembuatan prioritas dan pengambilan keputusan. Kinerja dan kepatuhan dipantau berdasarkan arah dan tujuan yang disepakati. Manajemen merencanakan, membangun, menjalankan dan memantau aktivitas, sejalan dengan arahan yang ditetapkan oleh tata kelola tubuh, untuk mencapai tujuan perusahaan.

COBIT 2019 dikembangkan berdasarkan dua set prinsip: Pertama prinsip yang mendeskripsikan persyaratan inti dari sistem tata kelola untuk informasi, dan teknologi perusahaan terdiri atas enam prinsip yang ditunjukkan pada Gambar 1, dan yang kedua prinsip kerangka tata kelola yang dapat digunakan untuk membangun sistem tata kelola untuk perusahaan terdiri atas 3 prinsip yang ditunjukkan pada Gambar 2 .

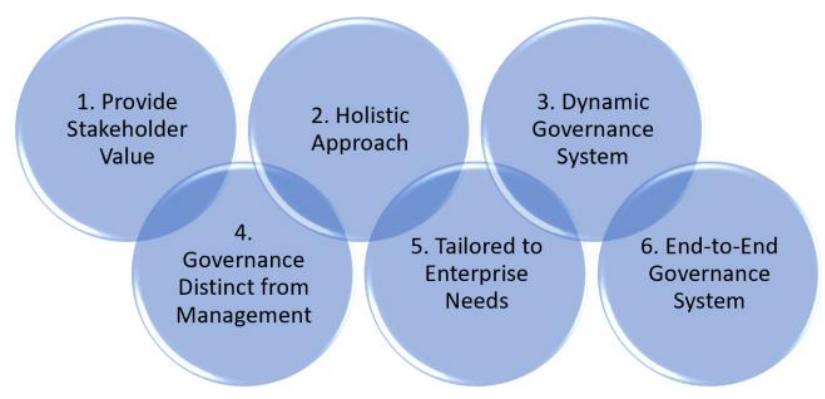

Gambar 1. Prinsip COBIT 2019 untuk sistem perusahaan

Tujuan tata kelola dan manajemen pada framework COBIT 2019 terdiri atas 5 domain, yaitu:

1. EDM (Evaluate Direct Monitor), governance area mengevaluasi pilihan strategis, selanjutnya memberikan arahan kepada senior manajemen pada pilihan strategis yang dipilih dan memantau pencapaian strategis yang dipilih. Terdiri atas 5 proses. 
2. APO (Build Acquire Implement), membahas keseluruhan organisasi, strategi, dan aktivitas pendukung untuk I\&T. Terdiri atas 14 proses.

3. BAI (Build Acquire Implement), membahas tentang cara mendefinisikan, mengakuisisi, dan mengimplementasi solusi I\&T dan integrasi mereka dalam proses bisnis. Terdiri atas 11 proses.

4. DSS (Deliver Service Support), membahas 6 proses pengiriman operasional dan dukungan layanan IT.

5. MEA (Monitor Evaluate Assess), membahas 4 proses, yaitu pemantauan kinerja dan kesesuaian IT dengan internal target kinerja, tujuan pengendalian internal, dan persyaratan eksternal.

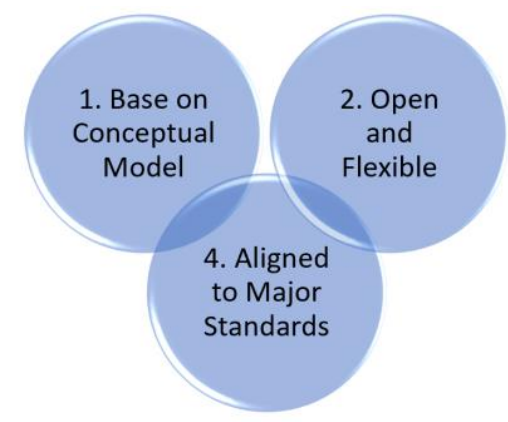

Gambar 2. Prinsip COBIT 2019 untuk sistem pemerintahan

Beberapa resiko yang mungkin terjadi di infrastruktur pada saat operasional IT, antara lain :

- Kerusakan peralatan IT yang tidak disengaja

- Kesalahan yang dilakukan oleh staf IT

- Masukan informasi yang tidak benar oleh staff IT atau oleh pengguna sistem

- Penghancuran pusat data (sabotase, dll.) oleh staf

- Pencurian perangkat dengan data sensitif

- Pencurian komponen infrastruktur utama

- Konfigurasi yang salah dari komponen perangkat keras

- Gangguan yang disengaja dengan perangkat keras (perangkat keamanan, dll.)

- Penyalahgunaan hak akses dari peran sebelumnya untuk mengakses infrastruktur TI

- Kehilangan media cadangan atau cadangan tidak diperiksa efektivitasnya

- Hilangnya data oleh penyedia cloud

- Gangguan layanan operasional oleh penyedia cloud

- Faktor desain mempengaruhi dalam berbagai cara menyesuaikan sistem tata kelola perusahaan.

Komponen sistem tata kelola merupakan faktor yang secara individual atau kolektif berkontribusi terhadap operasional IT. Sehubungan dengan itu, keberhasilan penerapan tata kelola dan managemen IT, sistem tatakelola digunakan oleh COBIT 2019 [14].

DSS merupakan domain COBIT 2019 yang berhubungan dengan operasional IT, seperti pemberian layanan, pengelolaan keamanan dan kontinuitas, dukungan layanan pengguna, dan pengelolaan data dan fasilitas operasional [15]. Dalam domain DSS terdapat Sub-domain DSS01, dimana subdomain ini merupakan prosedur aktivitas yang lebih detail mengenai "Memelihara dan menjalankan prosedur operasional dan tugas operasional secara andal dan konsisten". Di dalam DSS01 terdapat 5 practice name yaitu Perform operational procedure (DSS01.01), Manage Outsourced I\&T services (DSS01.02), Monitoring I\&T Infrastructure (DSS01.03), Manage the environment (DSS01.04), dan Managed facilities (DSS01.05). Pada Sub-domain DSS01 terdapat 33 aktivitas atau pertanyan-pertanyaan yang akan dilakukan pada proses audit.

\section{B. Domain DSSO1 (Deliver Service Support 01)}

Dalam domain DSS terdiri atas DSS01 sampai DSS06. DSS01 merupakan prosedur aktivitas yang lebih detail mengenai "Memelihara dan menjalankan prosedur dan tugas operasional tidak saja secara andal, tapi juga konsisten". Untuk DSS01 sendiri terdiri atas 5 practice name yaitu Perform operational procedure (DSS01.01), Manage Outsourced IT services (DSS01.02), Monitoring IT Infrastructure (DSS01.03), Manage the environment (DSS01.04), dan Managed facilities (DSS01.05). Pada Sub-domain DSS01 terdapat 33 aktivitas atau pertanyanpertanyaan yang akan dilakukan pada proses audit.

\section{Metode}

Metode yang digunakan pada penelitian di Poltesa ini yaitu metode Action Research. Dalam melakukan audit layanan TI terdapat 5 tahapan yang dilakukan, yaitu:

- Perencanaan (planning), pada tahap ini melakukan studi literatur, perumusan masalah, menentukan tujuan yang ingin dicapai dan membuat batasan masalah.

- Tindakan (action), pada tahap ini adalah menentukan domain apa yang akan digunakan.

- Mengamati (observing), pada tahap ini dilakukan pengumpulan data, dimana metode pengumpulan data yang dilakukan yaitu, melakukan observasi, wawancara kepada pihak yang bersangkutan serta melakukan kuisioner.

- Pengolahan dan analisis data

- Rekomendasi, rekomendasi dari hasil audit yang dilakukan bertujuan untuk mencapai target yang ingin dicapai, yang berguna untuk kemajuan perguruan tinggi.

\section{A. Metode Pengumpulan Data}

Pada penelitian ini digunakan metode teknik pengumpulan data yaitu:

- Studi Literatur, dengan cara mencari informasi dari berbagai sumber, paper, jurnal, buku serta dokumen lain yang terkait dengan penelitian ini.

- Metode Observasi, dengan cara melakukan pengamatan langsung pada objek yang diteliti, baik menggunakan panca indera atau juga peralatan bantu lain seperti kamera dan peralatan elektronik lainnya. 
- Metode Wawancara, dengan cara melakukan wawancara secara langsung maupun menggunakan media seperti telepon media daring seperti aplikasi chat di media sosial atau platform lainnya. Metode wawancara merupakan metode yang cukup baik dilakukan pada saat melakukan audit karena pertanyaan-pertanyaan yang diajukan akan mendapatkan jawaban yang lebih detail serta pemahaman dari jawaban yang diberikan akan bisa lebih dimengerti.

- Metode kuesioner, dengan cara membuat pertanyaan-pertanyaan atau kuesioner berdasarkan panduan yang terdapat pada framework COBIT 2019, kemudian dikombinasikan dengan capability level pada standar Capability Maturity Model Integration (CMMI). dengan kombinasi tersebut diharapkan hasil dari asesmen sesuai dengan kenyataan di lapangan, sehingga rekomendasi yang akan diberikan dari hasil audit akan bermanfaat untuk kemajuan perguruan tinggi.

\section{B. Menghitung tingkat Maturity Metode Capability Maturity Model Integration (CMMI)}

Dalam COBIT 2019, konsep pengukuran implementasi tata kelola dan manajemen IT yang digunakan adalah manajemen kinerja COBIT yang selaras dengan CMMI V2 [14]. Capability level berlaku untuk pencapaian kinerja IT pada institusi dan peningkatan proses pada area praktik individual. Pada Tabel 1 dapat dilihat tingkatan dari capability level.

TABEL I

CAPABILITY LEVEL CMMI

\begin{tabular}{|c|l|l|}
\hline Level & $\begin{array}{c}\text { Capability } \\
\text { Level }\end{array}$ & \multicolumn{1}{c|}{ Deskripsi } \\
\hline 0 & Incomplete & Tidak dilakukan \\
\hline 1 & Performed & Dilakukan, tidak berkala \\
\hline 2 & Managed & Dilakukan secara berkala \\
\hline 3 & Defined & Dilakukan dengan SOP \\
\hline 4 & Quantitatively & Dilakukan dan dimonitori \\
\hline 5 & Optimizing & $\begin{array}{l}\text { Dilakukan, dimonitori, dan } \\
\text { dikembangkan }\end{array}$ \\
\hline
\end{tabular}

Capability Maturity Model Integration (CMMI) adalah kelanjutan dari Capability Maturity Model (CMM) yang dirilis pada akhir tahun 90-an. CMMI merupakan sebuah framework atau kerangka kerja yang bisa dimanfaatkan untuk melaukan peningkatan unjuk kerja suatu organisasi atau suatu proses bisnis pada suatu organisasi. Initiate, Managed, Defined, Quantitatively, Managed, dan Optimizing merupakan level atau tingkatan dari framework CMMI. Gambar 3 Menunjukan Process Capability Level dari COBIT 5 dan COBIT 2019.

Pada penelitian ini digunakan kerangka kerja Capability Maturity Model Integration (CMMI) untuk mengukur maturity level. Tabel 2 menunjukkan tingkat maturity level. Maturity Model terdiri dari beberapa urutan tingkat kematangan yang menggambarkan kondisi dari suatu organisasi atau bisa juga sebuah proses.

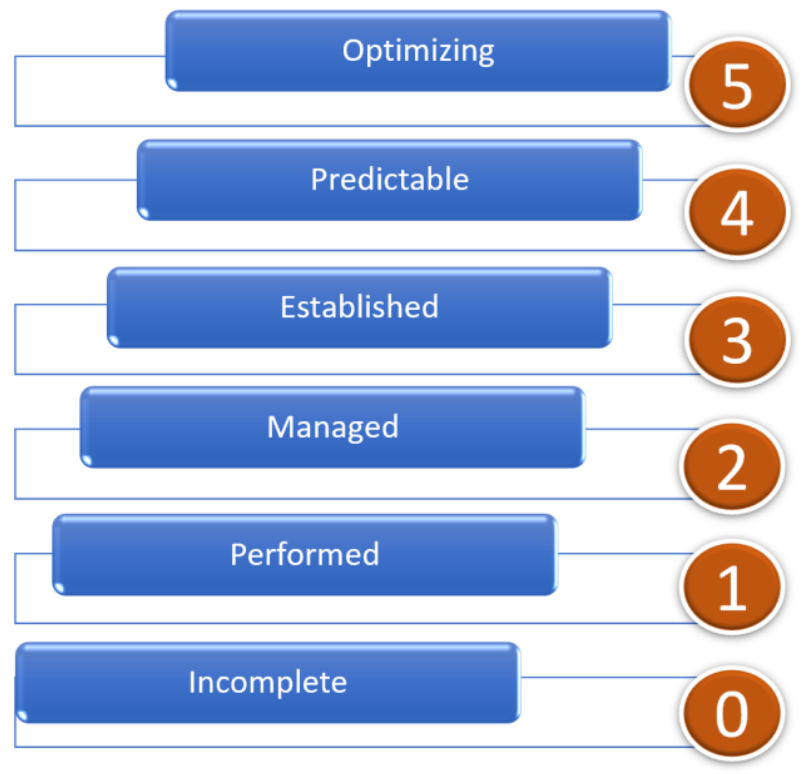

Gambar 3. Process Capability Level COBIT 5 dan COBIT 2019

TABEL II

MATURITY LEVEL CMMI

\begin{tabular}{|c|l|l|}
\hline Level & $\begin{array}{c}\text { Maturity } \\
\text { Level }\end{array}$ & \multicolumn{1}{c|}{ Penjelasan } \\
\hline 1 & Initiate & $\begin{array}{l}\text { Menjalankan aktivitas IT secara ad- } \\
\text { hoc dan reaktif }\end{array}$ \\
\hline 2 & Managed & $\begin{array}{l}\text { Menjalankan aktivitas IT tanpa } \\
\text { syarat dan belum ada prosedur }\end{array}$ \\
\hline 3 & Defined & $\begin{array}{l}\text { Menjalankan aktivitas IT } \\
\text { berdasarkan ketentuan, tetapi tidak } \\
\text { ada kontrol yang jelas }\end{array}$ \\
\hline 4 & Quantitatively & $\begin{array}{l}\text { Menjalankan aktivitas IT secara } \\
\text { terstandarisasi, terukur, dan } \\
\text { terkontrol }\end{array}$ \\
\hline 5 & Optimizing & $\begin{array}{l}\text { Menjalankan aktivitas IT } \\
\text { menggunakan dukungan teknologi } \\
\text { dengan peningkatan IT yang } \\
\text { berkelanjutan }\end{array}$ \\
\hline
\end{tabular}

\section{HASIL DAN PEMBAHASAN}

\section{A. Analisis Maturity Level}

Setelah melakukan survey dan melakukan perhitungan pada masing-masing proses pada domain PO, tingkatan rata-rata maturity level pada domain DSS01.01 sampai DSS01.02 yang telah dicapai oleh Poltesa seperti pada Tabel 3.

TABEL III

NILAI RATA-RATA DOMAIN

\begin{tabular}{|l|c|c|}
\hline \multicolumn{1}{|c|}{ Domain } & Nilai Rata-rata & Nilai Maksimal \\
\hline DSS01.01 & 2,45 & 5 \\
\hline DSS01.02 & 3,50 & 5 \\
\hline DSS01.03 & 3,00 & 5 \\
\hline DSS01.04 & 3,50 & 5 \\
\hline DSS01.05 & 4,00 & 5 \\
\hline DSS01.06 & 2,00 & 5 \\
\hline DSS01.07 & 4,00 & 5 \\
\hline Rerata & 3,21 & 5 \\
\hline
\end{tabular}


Hasil pengolahan data perhitungan Maturity Level menunjukan, rata-rata yang telah di dapat Poltesa adalah 3,21 berada pada level 3 (defined process). proses ini didasari pada proses pengembangan produk yang telah diintegrasikan dimana produk baru didokumentasikan pada proses standar pada level ini.

\section{B. Analisis Kesenjangan (Gap Analysis)}

Analisis kesenjangan diawali dengan melakukan pengukuran Maturity Level pada setiap domain terhadap tata kelola IT pada Poltesa. Selanjutnya dilakukan analisis gap Maturity Level saat penelitian dilakukan dengan Maturity Level yang diharapkan. Dari hasil perbandingan Maturity Level dan nilai kesenjangan, selanjutnya diberikan rekomendasi-rekomendasi yang sesuai sehingga diharapkan kedepan Poltesa dapat mengoptimalkan nilai kesenjangan yang ada. Gap antara target Maturity Level dengan nilai Maturity Level saat penelitian ini dilakukan dapat dilihat pada Tabel 4.

TABEL IV

HASIL ANALISIS KESENJANGAN

\begin{tabular}{|c|c|c|c|}
\hline Domain & $\begin{array}{c}\text { Indeks } \\
\text { Maturity Level } \\
\text { Saat Ini }\end{array}$ & $\begin{array}{c}\text { Indeks Maturity } \\
\text { Level yang } \\
\text { Diharapkan }\end{array}$ & Gap \\
\hline DSS01.01 & 2 & 3 & 1 \\
\hline DSS01.02 & 3 & 4 & 1 \\
\hline DSS01.03 & 3 & 3 & 0 \\
\hline DSS01.04 & 3 & 4 & 1 \\
\hline DSS01.05 & 4 & 4 & 0 \\
\hline DSS01.06 & 2 & 3 & 1 \\
\hline DSS01.07 & 4 & 4 & 0 \\
\hline
\end{tabular}

Nilai Maturity Level seluruh proses pada domain berada pada batasan nilai 2,00 sampai dengan 4,00. Dari analisis tersebut dapat disimpulkan bahwa segala kegiatan, mulai dari pengadaan, pemeliharan, sampai dengan pengawasan, dilakukan sesuai dengan kebutuhan tanpa dilakukan perencanaan. Gap antara Maturity Level saat penelitian ini dilakukan dengan Maturity Level yang diharapkan tidak terlalu besar, yaitu sebesar 1. Penentuan gap tersebut berdasarkan analisis kebutuhan pada Poltesa.

\section{Rekomendasi}

Dari hasil analisis kesenjangan yang telah dilakukan, hal-hal yang direkomendasikan untuk mengatasi gap dari capability level diantaranya adalah : Semua sistem informasi yang ada di Poltesa harus disediakan SOP, mengevaluasi dan mengontrol proses kinerja pada sistem informasi Poltesa, menetapkan menetapkan tugas dan penanggung jawab, serta selalu mendokumentasikan semua proses dari sistem informasi. Proses perbaikan dan penyempurnaan IT di Poltesa harus diupayakan secara brkesinambungan, hal ini merupakan proses pembelajaran yang mana tiap tingkatan pengembangan harus dilalui. Dalam penelitian ini didapatkan beberapa temuan yang berhubungan dengan penerapaan kontrol yang terlalu lemah.

\section{KESIMPULAN}

Berdasarkan hasil dari penelitian yang dilakukan pada Poltesa, kesimpulan yang didapatkan sebagai berikut:

1. Nilai rerata Maturity Level adalah 3,21 pada domain antara nilai 2 sampai dengan 4. Hasil nilai ini menunjukkan bahwa sistem IT di Poltesa belum secara maksimal dalam pengoperasiannya.

2. Gap yang ada antara rekomendasi level dengan ratarata level saat penelitian ini dilakukan menunjukkan gap yang tidak terlalu besar, sehingga apa yang diharapkan dapat dipenuhi dan dijalankan dengan baik oleh Poltesa.

3. Poltesa dapat melakukan peningkatan Maturity Level agar sesuai dengan target yang dicapai dengan memperhatikan rekomendasi-rekomendasi yang diberikan.

\section{REFERENSI}

[1] M. S. Lamato, A. Setyanto, A. Nasiri, U. Negeri, and G. Ung, "Evaluasi Tingkat Kematangan Tata Kelola Infrastruktur IT Menggunakan COBIT 5," e-Jurnal JUSITI (Jurnal Sist. Inf. dan Teknol. Informasi), vol. 82, no. 2, pp. 186-197, 2019, doi: 10.36774/jusiti.v8i2.619.

[2] S. Majid, "Audit Tata Kelola Teknologi Informasi pada Dinas Komunikasi dan Informatika (DISKOMINFO) Kota Bandar Lampung Menggunakan Kerangka Kerja COBIT 4.1 Domain Plan and Organise dan Acquire and Implement," vol. 2, no. 9, pp. 3425-3432, 2019, doi: 10.31219/osf.io/yuehf.

[3] D. Lanter, Introduction and Methodology. ISACA, 2018

[4] Elly and F. Halim, "Evaluasi Tatakelola Infrastruktur Ti Dengan Framework Cobit 5 ( Studi Kasus : Stmik - Stie Mikroskil )," Sebatik, vol. 5, pp. 74-82, 2016

[5] S. H. Supangkat, Institut Teknologi Bandung. School of Electrical Engineering and Informatics, Institut Teknologi Bandung. Informatics Engineering Group, and Institute of Electrical and Electronics Engineers., "2019 International Conference on ICT for Smart Society (ICISS): 'Innovation and Transformation Toward Smart Region' : proceeding : Bandung, 19 - 20 November 2019," vol. 2019, 2019

[6] T. Rahayu, N. Matondang, and B. Hananto, "Audit Sistem Informasi Akademik Menggunakan Metode Cobit 5 ( Studi Kasus UPN Veteran Jakarta ) Metode Pengumpulan Data Alur Penelitian Metode Analisis Data," J. Teknol. Inf. dan Pendidik., vol. 13, no. 305, 2020.

[7] H. Fryonanda, H. Sokoco, and Y. Nurhadryani, "Evaluasi Infrastruktur Teknologi Informasi Dengan Cobit 5 Dan Itil V3," JUTI J. Ilm. Teknol. Inf., vol. 17, no. 1, p. 1, 2019, doi: 10.12962/j24068535.v17i1.a717.

[8] R. Damayanti and A. D. Manuputty, "A Analysis Of Information Technology Governance In Department of Communication And Informatics of Salatiga Using COBIT 5 Framework DSS Domain," J. Inf. Syst. Informatics, vol. 1, no. 2, pp. 97-122, 2019, doi: 10.33557/journalisi.v1i2.12.

[9] A. Arumana, A. F. Rochim, and I. P. Windasari, "Analisis Tata Kelola Teknologi Informasi Menggunakan Kerangka Kerja COBIT 4.1 pada Fakultas Teknik Undip," J. Teknol. dan Sist. Komput., vol. 2, no. 2, pp. 162-169, 2014, doi: 10.14710/JTSISKOM.2.2.2014.162-169.

[10] H. Kusbandono and D. Ariyadi, "Rekomendasi Perbaikan Infrastruktur TI SMK Berdasarkan Evaluasi Tingkat Kematangan Framework COBIT 5," J. Appl. Informatics Comput., vol. 2, no. 2 pp. 9-14, 2018, doi: 10.30871/jaic.v2i2.1038.

[11] E. Nachrowi, Y. Nurhadryani, and H. Sukoco, "RESTI journal," Eval. Gov. Manag. Inf. Technol. Serv. Using Cobit 2019 ITIL 4, vol. 4, no. 4, pp. 764-774, 2020.

[12] A. Handayani and I. Imelda, "Audit Teknologi Informasi Pada CV. X”, JATI, vol. 3, no. 2, pp. 67-100, Sep. 2013. 
[13] F. Adikara. "Implementasi Tata Kelola Teknologi Informasi Perguruan Tinggi Berdasarkan Cobit 5 pada Laboratorium Rekayasa Perangkat Lunak Universitas Esa Unggul.” Seminar Nasional Sistem Informasi Indonesia, 2 - 4 Desember 2013

[14] A.A. Mohamad, Mulyana Dicky R, Mulyawan Ali, "Perbandingan Cobit 2019 dan ITIL V4 Sebagai Panduan Tata Kelola dan Management IT," Jurnal Computech \& Bisnis, Vol. 13, No. 2, Desember 2019, 100-105

[15] L. Nur, Junior Kenan Aldez, Daryanto, Purba Dormian Putriani, Simbolon Olgalina Okto, Rahmayanti Veny,” Audit Sistem Informasi Aplikasi Scan Barcode E-Faktur Pajak menggunakan COBIT Framework 5.0 Domain DSS pada PT. Japan Asia Consultants," Informatika dan RPL, Vol. 2, No. 2, September 2020, Hal. 161-166. 